\title{
Sulphur metabolism and cellulase gene expression are connected processes in the filamentous fungus Hypocrea jecorina (anamorph Trichoderma reesei) Gabriela Gremel, Marcel Dorrer and Monika Schmoll*
} \author{
Getreidemarkt 9/1665, A-1060 Wien, Austria \\ Email: Gabriela Gremel - gabrielagremel@hotmail.com; Marcel Dorrer - mdorrer@hotmail.com; \\ Monika Schmoll* - mschmoll@mail.zserv.tuwien.ac.at \\ * Corresponding author
}

Address: Research Area of Gene Technology and Applied Biochemistry, Institute of Chemical Engineering, Vienna University of Technology

Published: 8 October 2008

BMC Microbiology 2008, 8:174 doi:10.1186/147|-2180-8-174
Received: 17 June 2008

Accepted: 8 October 2008

This article is available from: http://www.biomedcentral.com/I47I-2I80/8/174

(C) 2008 Gremel et al; licensee BioMed Central Ltd.

This is an Open Access article distributed under the terms of the Creative Commons Attribution License (http://creativecommons.org/licenses/by/2.0), which permits unrestricted use, distribution, and reproduction in any medium, provided the original work is properly cited.

\begin{abstract}
Background: Sulphur compounds like cysteine, methionine and S-adenosylmethionine are essential for the viability of most cells. Thus many organisms have developed a complex regulatory circuit that governs the expression of enzymes involved in sulphur assimilation and metabolism. In the filamentous fungus Hypocrea jecorina (anamorph Trichoderma reesei) little is known about the participants in this circuit.
\end{abstract}

Results: Analyses of proteins binding to the cellulase activating element (CAE) within the promotor of the cellobiohydrolase $c b h 2$ gene led to the identification of a putative E3 ubiquitin ligase protein named LIMPET (LIMI), which is an orthologue of the sulphur regulators SCON-2 of Neurospora crassa and Met30p of Saccharomyces cerevisiae. Transcription of lim I is specifically upregulated upon sulphur limitation and responds to cellulase inducing conditions. In addition, light dependent stimulation/shut down of cellulase gene transcription by methionine in the presence of sulphate was observed. Further, $\lim I$ transcriptionally reacts to a switch from constant darkness to constant light and is subject to regulation by the light regulatory protein ENVOY. Thus lim I, despite its function in sulphur metabolite repression, responds both to light as well as sulphur- and carbon source. Upon growth on cellulose, the uptake of sulphate is dependent on the light status and essential for growth in light. Unlike other fungi, growth of $H$. jecorina is not inhibited by selenate under low sulphur conditions, suggesting altered regulation of sulphur metabolism. Phylogenetic analysis of the five sulphate permeases found in the genome of $H$. jecorina revealed that the predominantly mycelial sulphate permease is lacking, thus supporting this hypothesis.

Conclusion: Our data indicate that the significance of the sulphate/methionine-related signal with respect to cellulase gene expression is dependent on the light status and reaches beyond detection of sulphur availability. 


\section{Background}

Gene transcription in filamentous fungi is influenced by a variety of external stimuli. Adaptation to nutrient conditions is one of them. Many sulphur compounds, especially cysteine, methionine and S-adenosylmethionine are essential for the viability of most cells [1]. Thus, many organisms have developed a complex regulatory circuit that governs the expression of enzymes involved in sulphur assimilation and metabolism. Appropriate mechanisms have been discussed in the filamentous fungi Aspergillus nidulans and Neurospora crassa as well as the yeast Saccharomyces cerevisiae (reviewed by [1]). Neurospora crassa CYS3 [2] and Saccharomyces cerevisiae Met4 [3] were described as positive-acting regulators of an entire set of genes involved in sulphur metabolism. SCONB in Aspergillus nidulans [4,5], SCON2 in Neurospora crassa $[6,7]$ and Met30 in Saccharomyces cerevisiae [8] on the other hand were identified as negative regulators. In recent years, the regulatory machinery of sulphur metabolism has been shown to be embedded in a more complex network, which also involves response to heavy metals [9] and is influenced by the supply of carbon and nitrogen in plants [10]. The SCF-ubiquitin-ligase complex SCF(Met30) participates in cadmium-induced regulation of the transcription factor Met4 [11] and thereby initiates a system wide cellular response. This SCF-ubiquitin ligase complex is also presumed to contribute to the detoxification of cadmium by increasing the glutathion levels needed for complexing this toxic heavy metal $[12,13]$. A similar mechanism is likely to be at work for detoxification of arsenate [14] and selenate [15].

The filamentous fungus Hypocrea jecorina (anamorph Trichoderma reesei) is to date the most important industrial producer of cellulases [16-18]. Nevertheless, the genome of this fungus comprises a lower number of genes encoding these degradative enzymes than found in other filamentous fungi [19]. The importance of cellulases as indispensable reagents in industries like the pulp and paper industry, detergent industry or clothing industry gives rise to attempts for elucidating the mechanisms lying behind cellulose signalling to cellulase gene expression in $H$. jecorina. Remarkable effort had thus been put into elucidation of the mechanisms involved in regulation of cellulase gene expression. Besides cellulose, also lactose and sophorose promote cellulase gene expression, while glycerol does neither promote nor prevent it. Formation of cellulases is regulated at the transcriptional level, and the expression of the different cellulase genes has been reported to be coordinate [20]. However, little is known still about how the cellulose signal from outside the cell is transduced to initiate production of the appropriate hydrolytic enzymes. The first signal transduction protein to be identified in the respective signalling pathway was the light regulatory protein ENVOY [21], which also lead to the finding that cellulase gene expression is modulated by light. Subsequent analyses revealed that this protein influences several regulatory pathways in $H$. jecorina and that its function is not limited to light response [22].

Studies on the promotors of the cellulase genes provide a thorough basis to climb up the signal transduction cascade starting from the target: Using cell-free extracts from sophorose-induced and non-induced mycelia as well as various fragments of the promotor sequence of the $\mathrm{H}$. jecorina cellobiohydrolase $c b h 2$, the nucleotide sequence 5'ATTGGGTAATA-3' was found to bind different protein complexes in electrophoretic mobility shift assays (EMSA) under the respective conditions [23]. The mentioned sequence was named $c b h 2$-activating element CAE. The presence of an intact copy of this motif was shown to be required for protein binding and wild-type levels of $c b h 2$ transcript [23]. While the HAP2/3/5 complex of $H$. jecorina was found to bind to the CCAAT-box of the cellulase activating element CAE within the $c b h 2$ promoter [24] the factor(s) binding to the second part of the motif therein, which shows an even stronger regulatory effect $(50 \%$ decrease in transcription efficiency upon mutation to $5^{\prime}$ ATTGGGTTTTA 3') than the CCAAT-box, have not been described.

The transcriptional regulation of cellulase gene expression has been subject to extensive research $[20,25]$, and among the regulatory factors of this process, ACE2 [26], and XYR1 $[27,28]$ have been shown to bind to sequence motifs related yet not similar to CAE in the promotors of cbh1 (ACE2; 5' GGCTAATAA 3') or xyn1 (XYR1; 5' GGCTAA 3'). Despite the fact that their binding to CAE within the $c b h 2$ promotor has not been proven yet, they are likely to contact this motif due to their involvement in regulation of $c b h 2$ expression.

Our study was aimed at a more detailed understanding of cellulase gene regulation at the promotor level. Application of the Yeast One Hybrid System should identify the regulatory factor(s) binding to CAE. Surprisingly, we found a putative E3 ubiquitin ligase, the homologues of which are involved in regulation of sulphur metabolism, to bind to this regulatory sequence. This result led to the hypothesis that sulphur signaling/metabolism and regulation could be interconnected processes. In order to test this hypothesis we used different cultivation conditions appropriate to delineate the involvement of this E3 ubiquitin ligase in both processes and more importantly the role of the sulphur source with respect to cellulose utilization in $H$. jecorina in general. We show that the respective gene not only responds to cellulase inducing conditions and to light, but also - as expected - to a decrease in sulphur availability. Since methionine seems to have a spe- 
cific function in regulation of cellulase gene expression under defined sulphur conditions, we tested its effect under conditions commonly used to analyse this process. Indeed, the strong light-dependent effect of increased methionine levels seen under defined sulphur conditions also occurs under these conditions i. e. in the presence of sulphate and peptone. Moreover, we detected a role of sulphate in cellulose utilization, but not glucose utilization in light. Subsequent screening of the H. jecorina genome for the presence of sulphate permeases revealed the lack of a homologue to the N. crassa predominantly mycelial sulphate permease CYS-14.

\section{Methods}

\section{Microbial strains and culture conditions}

$H$. jecorina (T. reesei) strain QM9414 (ATCC 26921), which is a second generation high cellulase producing mutant strain of wild-type QM6a and is commonly used for studies on this fungus representing wild-type conditions as well as the recombinant strain env $1^{\text {PAS-, }}$ which is lacking the PAS domain of the light regulatory protein ENVOY [21] were used throughout this study. H. jecorina was grown in submerged culture at $28^{\circ} \mathrm{C}$ in 1-liter Erlenmeyer flasks on a rotary shaker $(200 \mathrm{rpm})$ in $200 \mathrm{ml}$ of Mandels Andreotti minimal medium [29]. 1\% (w/v) of the carbon sources indicated with the respective experiments was used. $10^{8}$ conidia/l (final concentration) were used as inoculum. The replacement technique described by Sternberg and Mandels [30] was applied for inducing cellulase formation in mycelia by $1.5 \mathrm{mM}$ sophorose (final concentration), as described previously [23,31].

The medium for cultivation under sulphur limitation conditions contained the respective chlorides instead of the sulphates used in conventional Mandels Andreotti medium and was prepared as follows: The modified trace element solution contained $0.243 \mathrm{~g} / \mathrm{l} \mathrm{FeCl} \cdot 6 \mathrm{H}_{2} \mathrm{O}(0.90$ $\mathrm{mM}), 0.050 \mathrm{~g} / \mathrm{l} \mathrm{MnCl}_{2} \cdot 2 \mathrm{H}_{2} \mathrm{O}(0.31 \mathrm{mM}), 0.033 \mathrm{~g} / \mathrm{ZnCl}_{2}$ $(0.24 \mathrm{mM})$ and $0.100 \mathrm{~g} / \mathrm{l} \mathrm{CoCl}_{2} \cdot 6 \mathrm{H}_{2} \mathrm{O}(0.42 \mathrm{mM})$ and the $\mathrm{pH}$ was adjusted to 2.0 with hydrochloric acid. The mineral salt solution contained $2.27 \mathrm{~g} / \mathrm{l} \mathrm{NH}_{4} \mathrm{Cl}(42 \mathrm{mM})$, $4.00 \mathrm{~g} / \mathrm{l} \mathrm{KH} \mathrm{KO}_{4}(29 \mathrm{mM}), 0.50 \mathrm{~g} / \mathrm{l} \mathrm{MgCl} \mathrm{PO}_{2} \cdot 6 \mathrm{H}_{2} \mathrm{O}(2 \mathrm{mM})$, $0.80 \mathrm{~g} / \mathrm{l} \mathrm{CaCl}{ }_{2} \cdot 2 \mathrm{H}_{2} \mathrm{O}(5 \mathrm{mM})$ and $0.6 \mathrm{~g} / \mathrm{l}$ urea $(10 \mathrm{mM})$. A $0.1 \mathrm{M}$ phosphate buffer was prepared using a solution with $35.6 \mathrm{~g} / 1 \mathrm{Na}_{2} \mathrm{HPO}_{4} \cdot 2 \mathrm{H}_{2} \mathrm{O}(0.2 \mathrm{M})$ and $0.2 \mathrm{M}$ citric acid was added to adjust a pH of 5.0 (all chemicals by Merck, Germany). The culture medium was prepared combining $500 \mathrm{ml}$ mineral salt solution, $480 \mathrm{ml}$ phosphate buffer and $20 \mathrm{ml}$ trace element solution.

As sulphur source, the following three concentrations of L-methionine (Sigma-Aldrich, St. Louis, USA) were used: $0.05 \mathrm{mM}, 0.25 \mathrm{mM}$ and $5 \mathrm{mM}$ corresponding to limiting, low and high sulphur concentration, respectively [5].
Yeast strain YM4271 (MATa, ura3-52, his3-200, ade2101, lys2-801, leu2-3, 112, trp1-903, tyr1-501, gal4$\Delta 512$, gal80- $\Delta 538$, ade5::hisG $[32,33]$ was used as host strain for the One Hybrid System.

E. coli JM109 [34] was used for the propagation of vector molecules and DNA manipulations; E. coli ER1647 (Novagen, Madison, WI) was used for plating, titering and screening of the $\lambda$ Blue Star gene library; and $E$. coli strain BM25.8 (Novagen), which is lysogenic for $\lambda$ phages, was used for automatic subcloning. The latter two strains were grown at $37^{\circ} \mathrm{C}$ on LB medium supplemented with $0.2 \%$ $(\mathrm{w} / \mathrm{v})$ maltose and $10 \mathrm{mM} \mathrm{MgSO}$ for propagation of $\lambda$ phages. E. coli BL21 (DE3) (Stratagene, La Jolla, CA) was used for the expression of GST fusion proteins according to the recommendations of the manufacturers.

\section{Nucleic acid isolation and blotting}

H. jecorina DNA was isolated as described previously [31]. Yeast and E. coli DNA was isolated as described by Sambrook et al[35]. Total RNA was isolated by the guanidinium/phenol procedure [36]. Northern blotting was performed as described previously [31,35]. For transcript analysis of $\lim 1$ the insert of pOHS125 was excised and used for hybridization. Probes for analysis of transcription of env1, cbh1, cbh2 and 18S rRNA were prepared by PCR. Densitometric scanning was done using the BIORAD (Hercules, USA) GS-800 calibrated densitometer and the BIO-RAD Quantity One software for different exposures of the respective film.

\section{Construction of Reporter Plasmids and Yeast strains for One-hybrid screening}

Complementary oligonucleotides with three copies of the mutated CAE motif (oneH(F) 5' AATTCTCTTTAAAGGGT AATATACAGCCATCTTTAAAGGGTAATATACAGCCATCT TTAAAGGGTAATATACAGCCAT 3') containing the functional (GG)GTAATA-sequence and a non-functional CCAAT box [23] corresponding to positions - 253 to 220 of the cbh2 promoter were cloned into plasmids pHISi and pLacZi. For the construction of a negative control plasmid also the (GG)GTAATA sequence was mutated to (GG)GTTTTA in the oligonucleotide to abolish binding of the respective proteins [23]. The resulting plasmids were designated pHISi-CAE and pLacZi-CAE or pHISimCAE, respectively.

A reporter strain HIS-LACZ-CAE for the transformation of the cDNA library was constructed by integration of pHISiCAE and pLacZi-CAE into yeast strain YM4271. The negative control strain HIS-mCAE was obtained by integration of pHISi-mCAE into yeast strain YM4271. Plasmids and yeast strain YM4271 were included in the Matchmaker One Hybrid system kit (CLONTECH, Palo Alto, USA). 


\section{Construction of an Activation Domain tagged cDNA- Library from $\mathbf{H}$. jecorina by Directional cloning}

For preparation of cDNA, mycelia of the wild-type strain QM9414, grown under cellulase inducing conditions (sophorose) were used. mRNA was isolated from total RNA using the PolyATtract mRNA Isolation Kit (Promega, Madison, USA), and a cDNA library was constructed using the HybriZAP ${ }^{\mathrm{тм}}$ Two-Hybrid cDNA Gigapack ${ }^{\circledR}$ Cloning Kit (Stratagene Ltd., Cambridge, UK) according to the manufacturers instructions. After packaging by the Gigapack III Gold packaging extract (Stratagene Ltd, Cambridge, UK) and excision, the cDNA library containing $10^{6}$ independent clones within the vector pAD-GAL4-2.1 in frame to the GAL4 activation domain was used in the One Hybrid System.

Yeast One hybrid Screening of a $\mathbf{H}$. jecorina cDNA Library The yeast reporter strain HISLACZ-CAE was transformed using the lithium acetate/ssDNA/PEG method [37]. The resulting $3 \times 10^{5}$ yeast transformants were plated on his $/$ leu- selective media containing $50 \mathrm{mM}$ 3-aminotriazole (3-AT). The concentration of $50 \mathrm{mM}$ 3-AT was previously determined to be sufficient to suppress leaky expression of the marker gene. Positive transformants were additionally tested for $\beta$-galactosidase activity by a filter lift assay according to the manufacturer's instructions (Matchmaker One-Hybrid system Kit, CLONTECH). Plasmids from putative positive clones were isolated after homogenization with glass beads, amplified in E. coli JM109 [38], and retransformed into yeast strain HISLACZ-CAE and tested for growth in the presence of $50 \mathrm{mM}$ 3-AT. This step was followed by transformation of plasmids conferring histidine prototrophy into the negative control strain HISmCAE. The rationale was that the mutation abolishes protein binding in the yeast cell, and positive transformants should therefore be unable to grow on selective media.

\section{Cloning of chromosomal DNA of $\mathrm{H}$. jecorina}

To isolate the corresponding genomic clones, the cDNA fragment obtained from the experiment was used as probe to screen a genomic $\lambda$ Blue Star (Novagen, Madison, Wis.) library of $H$. jecorina QM9414. Positive clones were excised from the phages by automatic subcloning following the instructions of the manufacturer. The sequence was crosschecked with the Trichoderma reesei Genome database v2.0 [39].

\section{3' RACE}

First strand synthesis was performed using the Reverse Transcription System (Promega, Madison, USA) according to the manufacturers protocol at $42^{\circ} \mathrm{C}$ for 1 hour with primer RACE-N (5' GCGTAATACGACTCACTATAGGGCGAATTGGGTTTTTTTTTTTTTTTTT(AGC) 3'). The reaction mixture was cleaned up using the QIAquick PCR Cleanup Kit (QIAGEN). PCR and Nested PCR were per- formed according to standard protocols using a gene specific primer and primer RACE-N22 (5' GCGTAATACGACT CACTAT AGG 3').

\section{Determination of biomass formation from cellulose grown cultures}

After 96 hours of growth on microcrystalline cellulose either in light or in darkness, mycelia were harvested by centrifugation and $5 \mathrm{ml} 0.1 \mathrm{~N} \mathrm{NaOH}$ were added to the pellet. The sample was sonicated for 3 minutes and incubated for 3 hours at room temperature. Following centrifugation, protein content of the supernatant representing biomass content of the sample was determined using the BIO-RAD Protein assay (BIO-RAD, Hercules, US). Samples were analyzed in triplicates from independent cultivations.

\section{Purification of glutathione S-transferase fusion proteins}

The cDNA-insert encoding $\mathrm{aa}_{457}-\mathrm{aa}_{636}$ of LIM1 as isolated with the One Hybrid system was cloned into vector pGEX4T-1 (Stratagene). E. coli BL21 (Stratagene) was transformed with the expression construct. Expression and purification by glutathione sepharose 4B (Amersham Pharmacia Biotech, Uppsala, Sweden) affinity chromatography was essentially performed as described previously [40]. Fusion proteins were eluted using $50 \mathrm{mM}$ Tris- $\mathrm{HCl}$, pH 8.0, $10 \mathrm{mM}$ glutathione and $2 \mathrm{mM}$ dithiothreitol. All protein preparations were stored at $-80^{\circ} \mathrm{C}$ in the presence of $20 \%(\mathrm{w} / \mathrm{v})$ glycerol.

\section{Electrophoretic mobility shift assay}

Electrophoretic mobility shift assays were performed as described by Stangl et al[41]. The oligonucleotides were end-labelled with $\left(\alpha-{ }^{32} \mathrm{P}\right)$-dCTP, using Sequenase version 2.0 (Amersham, Little Chalfont, UK). After purification by nondenaturing polyacrylamide gel electrophoresis binding was achieved by incubating $5 \mu \mathrm{g}$ of protein with $5 \mathrm{ng}$ of labelled fragment at room temperature for $10 \mathrm{~min}$. GST-elution buffer (see above) containing 20\% glycerol and lacking protein was used as negative control (sample referred to as free probe).

\section{Phylogenetic analyses}

Amino acid sequences were aligned with Clustal X 1.81 [42] and then visually adjusted. Phylogenetic analyses were performed in MEGA 2.1 using the Minimum Evolution (ME) approach. Reliability of nodes was estimated by ME bootstrap percentages (BPME) [43] obtained after 500 pseudo-replications.

\section{Results \\ Identification of a protein that binds to CAE by the Yeast One Hybrid System}

We applied the yeast one hybrid system to identify proteins binding to CAE [23], as this approach allows to 
screen for DNA-protein interaction in vivo and thus bypasses common drawbacks of in vitro experiments such as altered binding characteristics caused by the experimental conditions or problems with the renaturation of the proteins in vitro [44-46].

We used a sequence comprising a CCAAT to CCTTT mutated CAE motif in order to prevent isolation of HAPcomplex proteins, which bind to this motif [24] as bait (Figure 1A). Application of the One Hybrid System and subsequent screening for $\beta$-galactosidase activity led to the isolation of several clones representing proteins putatively binding to the (GG)GTAATA motif. The respective, positive plasmids were tested by retransformation into both the reporter strain HIS-LACZ-CAE to confirm DNA binding and also the negative control strain HIS-mCAE, in which the binding sequence bait (GG)GTAATA had been replaced by (GG)GTTTTA (Figure 1A). The latter mutation has previously been shown to abolish binding of proteins from cell free extracts of $H$. jecorina to CAE in vitro and result in lack of cbh2-gene expression in vivo [23]. In this control experiment, positive clones showed specific interaction to the wild-type bait (i. e. growth on selective medium) and no interaction with the mutated bait (i.e. no growth on selective medium). Plasmid pOHS125A enabled growth upon transformation into the reporter strain on selective medium comparable to the transformation control, but not if transformed into the strain comprising the mutated CAE motif (Figure 1B). Hence binding of the protein encoded on pOHS125A to CAE was confirmed and the lack of growth upon transformation into the negative control strain showed that this interaction was specific and was not due to unspecific binding to the promotor outside the region of interest. pOHS125A, which contains a 1.057-bp cDNA insert encoding a putative WD-repeat domain protein, which as expected - was in frame with the GAL4 activation domain of the vector, was chosen for further investigation.

\section{The protein encoded on pOHSI 25 also binds to CAE in vitro}

Since the protein encoded on pOHS125 was cloned by its ability to bind to the CAE motif in vivo in the One Hybrid Assay, we wanted to confirm this result in vitro by Electrophoretic mobility shift assay. To this end, the cDNA-insert from pOHS125 (encoding $\mathrm{aa}_{457}-\mathrm{aa}_{636}$, which was functional in yeast) was cloned in frame into pGEX4T-1, expressed in E. coli as GST-fusion protein, purified and used in gel retardation assays. The EMSA analysis indicated that the fusion protein actually binds to the target sequence on the oligonucleotide oneH-CAE, albeit the interaction was very weak (Figure 1C).

\section{LIMPET encodes a WD-Repeat/F-box protein}

The 1.057-bp insert of pOHS125 was used to obtain a genomic clone and the 3 ' end as contained in pOHS125 was verified by 3'RACE. The predicted gene corresponds to the predicted protein tre77795 [39] and contains an open reading frame of 2004 bp interrupted by a 90 bp intron and encoding a 636 aa protein with a deduced molecular mass of $71.1 \mathrm{kDa}$. Despite its isolation on the basis of its ability to specifically bind to CAE, it lacks any of the known DNA-binding protein domains. A similar phenomenon was also reported earlier upon isolation of an SCF-component by the One Hybrid System [47]. Psort II analysis of the protein [48] revealed four nuclear localization sequences at amino acids 57, 186,196 and 239 and also predicted it as being localized to the nucleus according to Reinhardt's method for Cytoplasmatic/ Nuclear discrimination [49]. A cAMP and cGMP dependent phosphorylation site at amino acid position 186 was found. No N-terminal signal sequence was detected. The C-terminal part of the protein contains $7 \mathrm{WD}$ repeats (Figure 2) and the N-terminal part contains an F-box, a conserved motif first described by Kumar and Paietta [6]. Bai et al. [50] recognized that the F-box is a widespread motif required for protein-protein-interaction. A database search revealed that the encoded protein shows significant amino acid homology to several other WD-repeat/F-box containing proteins, highest identity and similarity among characterized proteins being obtained with SCON2 of Neurospora crassa [51] (GenBank accession number Q01277; 58\% and 71\%, resp.), SconB of Aspergillus nidulans [5], (GenBank accession number Q00659; 57\% and $72 \%$, resp.) and S. cerevisiae Met30p (GenBank accession number NP $012218 ; 40 \%$ and 56\%, resp.), all of them involved in the regulation of sulphur metabolism. Phylogenetic analysis of the 50 best hits in PSI-BLAST [52] revealed that it occurs at a basal position in a subclade containing other Sordariomycete proteins including SCON-2, which is part of a major, strongly supported clade also containing A. nidulans SconB (data not shown). The hierarchy of this tree is consistent with the present knowledge about evolution in the ascomycetes and therefore likely comprises the orthologues of SconB/SCON-2. Consequently, this protein is the H. jecorina orthologue of these two proteins. Analysis of the promotor revealed 4 GATA-type binding sites, whereas putative CYS-3 binding sites, which would be indicative of a control loop as present in N. crassa [6] are lacking. As the function of WDdomain/F-box proteins is in the attachment to other proteins, and to acknowledge its proposed function in cellulose signal transduction which has hot been reported from its closest orthologues, we have chosen to call this protein LIMPET (encoded by lim1). 


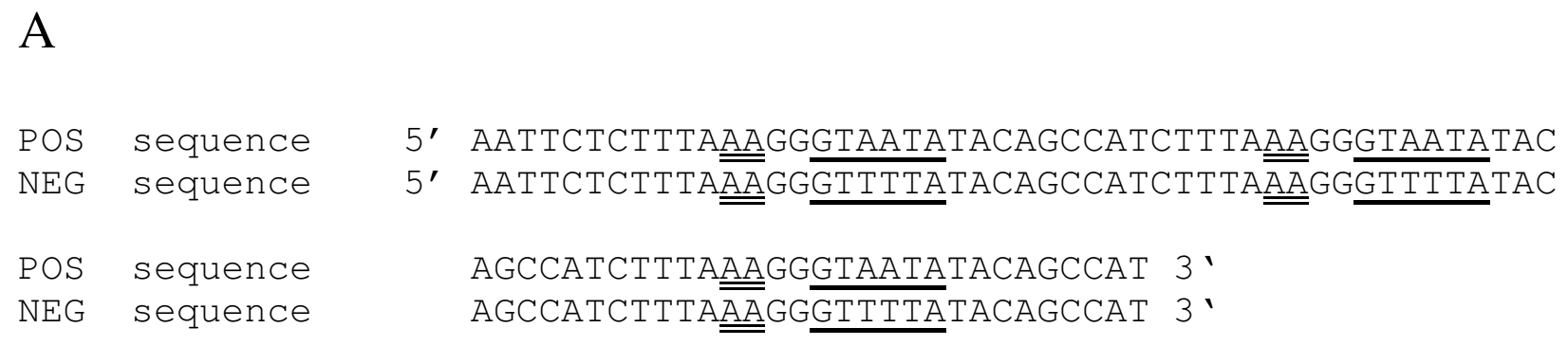

$\mathrm{B}$

$\mathrm{C}$

\begin{tabular}{|c|c|}
\hline & \multicolumn{2}{|c|}{ selective medium } \\
plasmid & SD -LEU $\quad$ SD -LEU -HIS \\
\hline & \\
pOHS125 & $\cdots$ \\
& \\
\hline
\end{tabular}

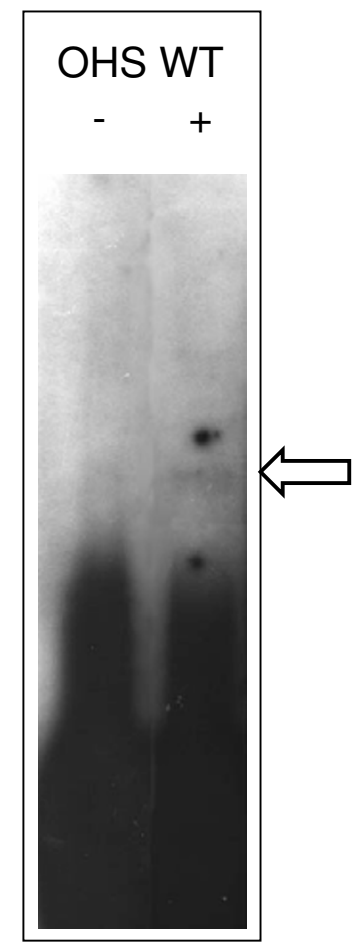

\section{Figure I}

Identification of the CAE-binding protein by the One Hybrid System. (A) Sequences of oligonucleotides used for the in vivo yeast assay (POS; (GG)GTAATA; used to construct PHIS-CAE) and the negative control experiment (NEG

(GG)GTTTTA; used to construct pHIS-mCAE). (B) Negative control experiment using pHIS-mCAE containing yeast strains transformed with pOHSI25. Growth on synthetical dropout medium lacking leucine (SD-LEU; numerous colonies) indicates successful transformation, inability to grow on SD-LEU-HIS (empty plate, no colonies) confirms that due to the mutation of (GG)GTAATA to (GG)GTTTTA DNA binding of the protein encoded on POHSI 25 is abolished and therefore sequence specific. A detail of the plates after the transformation is shown, equal amounts of transformation mix were plated on both positive and negative selection medium. (C) Electrophoretic mobility shift assay using $5 \mathrm{ng}$ of labeled oneH-CAE as oligonucleotide and $5 \mu \mathrm{g}$ of a GST-fusion protein with LIMPET $\mathrm{aa}_{457}-\mathrm{aa}_{636}(+)$ which was functional in yeast. GST-elution buffer (see Materials and Methods) containing $20 \%$ glycerol and lacking protein was used as negative control (-; free probe). The complex formed is indicated by an arrow. 
$\left\{\left[\begin{array}{llll}G H & (27 \pm 2 & \text { aa }) & \text { WD }\end{array}\right]\right.$ core length
$(11 \pm 2$ aa) ] $\}$ variable length

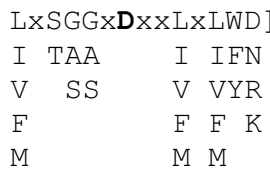

FKGHENGITCLQF LRGHTSTIRTLQF LQGHTDGVLS IHF LRGHSDWVNHVRI YLGHVGQVQQ I LL
(DHNI) LATGSYDTTIKIWN (DDAK) LISGSEDKTIKIWN (DGCK) LASGSIDKTVKIFS

(DSASRT) VFSASDDLSVKLWD
$4-8$

number of

repeats

$(x 9 \pm 2)$

(VETGTCIRT)

(WHTGECIST)

(FDTKYTWT)

(LDSKQCIKT)

(MPPDFEPDEDPNADRGDAASALWDLDTRQVIRTYEGH VGHVQQVLILPPEYEPDEEVLNGASQDNQDAMSVLPDQSTDRRAAFGYGFTSDPARPLPPRY) *

$\begin{array}{lllll} & & & \text { MLTGGLDNTVRLWD } & \text { (IATGKCIRS) } \\ \text { Repeat } 6 & \text { MFGHVEGIWGLVG } & \text { (DTLR) } & \text { VVTGANDSMTKIWE } & \text { (PRSGKCERS) } \\ \text { Repeat } 7 & \text { FTGHAGPVTCVGL } & \text { (SDSR) } & \text { MASGSEDGEVRLYS } & \end{array}$

Figure 2

Consensus sequence of WD40 repeats according to Neer et al., [72] and WD40 repeats of LIMPET. (*represents an unusually long spacer region).

\section{lim I is regulated in dependence of sulphur availability} Because of the in silico identification of LIMPET as a regulator of sulphur metabolism, regulation of $\lim 1$ was tested for its regulation under different levels of sulphur source availability. In order to ensure comparability to earlier studies we chose conditions similar to those used to investigate transcription of the respective orthologues in $\mathrm{Neu}$ rospora crassa (SCON-2) or Aspergillus nidulans (SconB) [5,6]. Therefore H. jecorina QM9414 was cultivated on sulphate free Mandels Andreotti minimal medium in the presence of glycerol as sole carbon source supplemented with methionine as the only sulphur source at high (5 $\mathrm{mM})$, low $(0.25 \mathrm{mM})$ or limiting $(0.05 \mathrm{mM})$ concentration. The data shown in Figure 3 indeed confirm that, as its counterparts in Neurospora and Aspergillus, lim1 is transcribed only on limiting concentrations of methionine in the medium, thus supporting the hypothesis that LIMPET is an orthologue of these two sulphur regulators.

\section{LIMPET responds to cellulase-inducing conditions}

The isolation of LIMPET as a (potentially regulatory) protein binding to the cellulase activating element CAE suggests a function in induction and/or regulation of cellulase gene expression. Therefore we analyzed whether lim1 would transcriptionally react to a shift to inducing conditions. Again we chose conditions shown to strongly induce cellulase gene expression in earlier studies [23,31] and at the same time would reveal a short term response to inducing conditions. Strain QM9414 was grown on Mandels-Andreotti minimal medium with $1 \%(\mathrm{w} / \mathrm{v})$ glyc- erol as sole carbon source for 24 hours in darkness and afterwards transferred to medium lacking the carbon source but supplemented with $1.5 \mathrm{mM}(0.05 \%)$ sophorose, which has a strong cellulase inducing effect [30]. Under these conditions sophorose cannot be regarded as

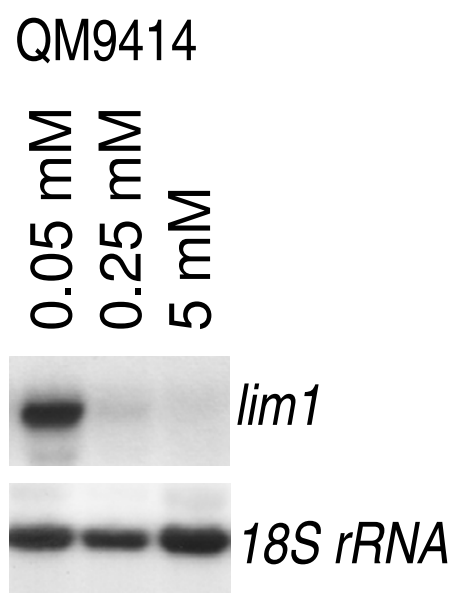

\section{Figure 3}

Northern analysis of transcription of lim I. Strains were cultivated for 72 hours on Mandels Andreotti minimal medium lacking sulphate with $1 \%(\mathrm{w} / \mathrm{v})$ glycerol as sole carbon source and supplemented with $0.05,0.25$ or $5 \mathrm{mM}$ methionine as specified with the samples. $20 \mu \mathrm{g}$ of total RNA were loaded per lane, a hybridization with I8S rRNA is given as a loading control. 
carbon source due to the extremely low amount, but only as an inducing agent for cellulase expression. Therefore the same medium without sophorose was used as control. In the presence of sophorose, transcript abundance after the shift to inducing conditions decreases as cellulase gene transcription increases (Figure 4). This effect was not due to the transfer to the new medium, because with the medium lacking sophorose neither the transcript abundance of $\lim 1$ decreases nor transcription of $c b h 2$ is induced. Thus $\lim 1$ transcriptionally reacts to the presence of the strong inducer sophorose i. e. cellulase inducing conditions in the opposite way as cellulase genes. These data are also consistent with the hypothesis that LIMPET could act as a negative regulator of cellulase formation.

\section{Sulphate is important for normal growth of $\mathrm{H}$. jecorina in light on cellulose}

The experiments described above suggest a function in both sulphur metabolism and cellulase gene expression. The latter has recently been shown to be influenced by light [21]. Consequently we analyzed whether growth of $H$. jecorina on cellulose would be influenced by the availability of the sulphur source and whether the light status would be important for this effect. In order to provide defined conditions with respect to sulphur availability the medium was altered according to [5]. The H. jecorina QM9414 was grown for 96 hours on sulphate free Man-

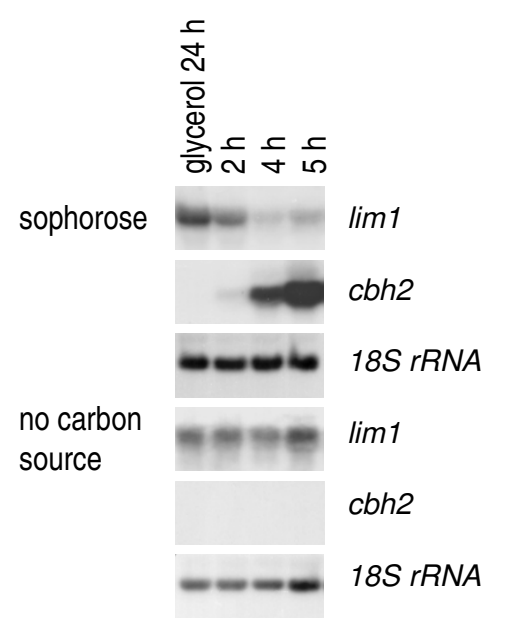

Figure 4

Northern analysis of transcription of $\lim I$ or $c b h 2$ after induction of cellulase gene expression. Cellulase gene expression was induced by replacement to medium containing $1.5 \mathrm{mM}$ sophorose or medium lacking carbon source in constant darkness. Strains were grown on Mandels Andreotti minimal medium with $1 \%(w / v)$ glycerol as carbon source for $24 \mathrm{~h}$ in darkness (preculture). Mycelia were harvested 2, 4 or 5 hours after replacement. $20 \mu \mathrm{g}$ of total RNA were loaded per lane, a hybridization with I8S rRNA is given as a loading control. dels Andreotti medium with 1\% (w/v) microcrystalline cellulose as carbon source and methionine as the only sulphur source in high $(5 \mathrm{mM})$, low $(0.25 \mathrm{mM})$ or limiting (0.05 mM) concentration in light and darkness. We observed a reduction of biomass formation in light of 80 to $95 \%$ as compared to growth in constant darkness was observed (Figure 5). Although significant changes in biomass formation due to different amounts of methionine in the medium were observed, the concentration of supplemented methionine as sulphur source could not compensate the growth defect in light and also had no major effect on growth in darkness. Under commonly used conditions, i.e. the conventional Mandels Andreotti medium (which contains approximately $12 \mathrm{mM}$ sulphate) corresponding to high sulphate concentration, $H$. jecorina only shows a decrease in biomass formation in liquid culture in light compared to growth in darkness of roughly $20 \%$ [21] after 96 hours of growth with microcrystalline cellulose as carbon source. Since the major difference of the two media used is their content of inorganic sulphate, which is lacking completely and replaced by different concentrations of the organic sulphur source methionine in one case, a role of inorganic sulphate as signal in processes related to light response seems possible. Nevertheless, an influence of the decreased amino acid availability in the sulphate free medium because of the lack of peptone as

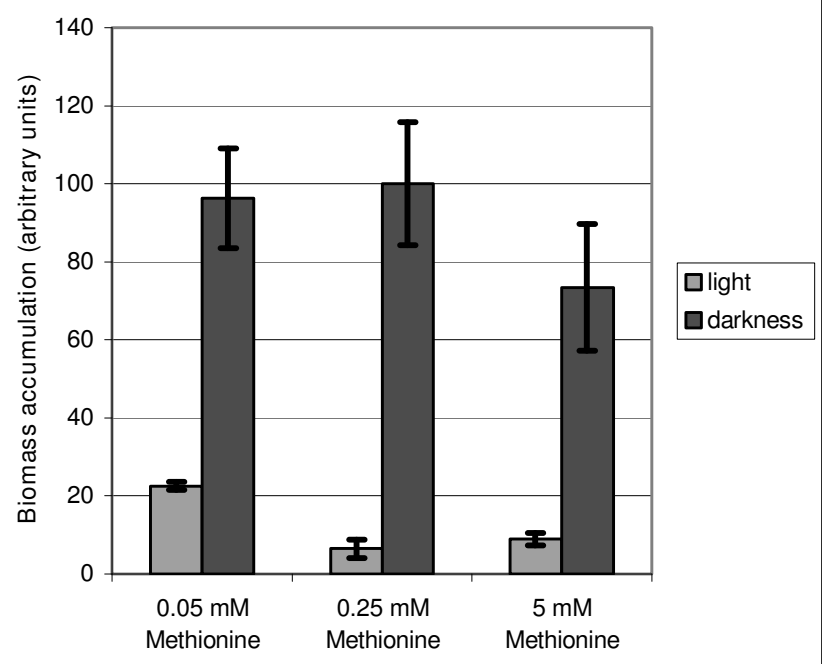

\section{Figure 5}

Biomass formation of wild-type strain QM94 I 4 in the presence of different sulphur concentrations. Biomass accumulation was measured after growth for 96 hours in either complete darkness or constant light (I 800 lux, 25 $\mu \mathrm{mol}$ photons $\left.\mathrm{m}^{-2} \mathrm{~s}^{-1}\right)$ on sulphate free Mandels-Andreotti medium with $1 \%(\mathrm{w} / \mathrm{v})$ of microcrystalline cellulose as carbon source supplemented with $0.05,0.25$ or $5 \mathrm{mM}$ methionine. Values were normalized to growth on $0.25 \mathrm{mM}$ methionine in constant darkness. 
compared to the conventional Mandels Andreotti medium cannot be excluded, but does not explain the huge difference in growth between darkness and light under otherwise equal conditions.

\section{Sulphate uptake is regulated by light in $\mathbf{H}$. jecorina}

The finding that light-dependent biomass formation of $H$. jecorina on cellulose is clearly altered upon growth in medium lacking sulphate led to the hypothesis that uptake of inorganic sulphur is important for growth on cellulosic substrates in light. This hypothesis was tested in the following. Sensitivity versus toxic sulphur analogons such as selenate and chromate has been reported under conditions of low organic sulphur in wild-type strains of Aspergillus nidulans as well as Neurospora crassa [5,51]. This phenomenon is due to derepression of the sulphate uptake, when the organic sulphur source becomes limiting [53]. Because of the chemical analogy of selenate to sulphate, both are taken up into the cell by the same permeases $[53,54]$ and also metabolism of selenate follows the same route as for sulphate [55]. The toxicity of selenate is consequently due to toxic by-products generated during reduction of selenate, which cause oxidative damage of DNA and addition of sulphate alleviates the toxicity of selenate $[54,56]$. Hence growth defects upon cultivation in the presence of selenate are indicative of selenate uptake into the cell. Considering the co-transport of sulphate and selenate such a growth defect also represents initiated sulphate uptake under the respective conditions.

Using plate experiments the presence of light-dependent regulation of sulphate uptake should be verified. Therefore plates containing sulphate free Mandels Andreotti medium with $1 \%(\mathrm{w} / \mathrm{v})$ of (soluble) carboxymethylcellulose, $0.05 \mathrm{mM}$ of methionine and either $1 \mathrm{mM}$ of $\mathrm{Na}_{2} \mathrm{SeO}_{4}$ or $2 \mathrm{mM}$ of $\mathrm{Na}_{2} \mathrm{SO}_{4}$ were inoculated with agar plugs taken from fully sporulated plates of strain QM9414. Afterwards they were exposed to light or kept in constant darkness under otherwise equal conditions at $28^{\circ} \mathrm{C}$ for four days.

In the presence of $0.05 \mathrm{mM}$ (limiting) methionine $\mathrm{Na}_{2} \mathrm{SeO}_{4}$ was supposed to inhibit the growth of the fungus due to sulphur metabolite derepression [5]. In fact $H$. jecorina was not inhibited as severely as expected in growth by the presence of selenate and limiting concentrations of methionine. The observed colony diameter after four days of incubation of strain QM9414 was only slightly decreased on selenate compared to sulphate in constant darkness $(2.7 \pm 0.1 \mathrm{~cm}$ on selenate or $3.0 \pm 0.1 \mathrm{~cm}$ on sulphate) i. e. by $10 \%$, but was clearly reduced in light $(2.5 \pm$ $0.3 \mathrm{~cm}$ on selenate or $3.8 \pm 0.2 \mathrm{~cm}$ on sulphate) i. e. by $35 \%$. No such substantial light-dependent difference in selenate sensitivity was observed when the same experi- ment was done using glucose as carbon source under otherwise equal conditions $(5.2 \pm 0.4 \mathrm{~cm}$ on selenate or $6.2 \pm$ $0.1 \mathrm{~cm}$ on sulphate in darkness $(16 \%)$ and $4.9 \pm 0.3 \mathrm{~cm}$ on selenate or $5.5 \pm 0.4 \mathrm{~cm}$ on sulphate in light $(12 \%))$. Interestingly, increased concentrations of selenate caused only a minor decrease in growth up to $3 \mathrm{mM}$ and no further decrease even with $10 \mathrm{mM}$ selenate (data not shown), which completely inhibits growth of Aspergillus and Neurospora. The conclusion that sulphate uptake is increased during growth on carboxymethylcellulose in light (and therefore inhibited by the presence of selenate) is in perfect agreement with the data of biomass formation on microcrystalline cellulose as described above.

\section{H. jecorina lacks a homologue of the predominantly mycelial sulphate permease}

After the finding of an obviously altered regulation of sulphate uptake in H. jecorina as compared to Neurospora or Aspergillus we wondered whether this alteration could be due to a different machinery available for regulation of sulphate metabolism in this fungus. Therefore we screened the Trichoderma reesei genome database v2.0 [39] for genes with similarity to the four sulphate permeases detected within the N. crassa genome [57]. Phylogenetic analysis of the five proteins (tre21550, tre38951, tre35211, tre45927 and tre75475) we identified, revealed that only three of them clustered with the sulphate permeases present in N. crassa (Figure 6, Table 1). N. crassa CYS-14 [53,58], the predominantly mycelial sulphate permease, seems to have no orthologue in H. jecorina. Only an orthologue of the second characterized, predominantly conidial sulphate permease, CYS-13 [53] is also present in $H$. jecorina (tre38951). This sulphate permease shares $49 \%$ amino acid identity to the $N$. crassa hypothetical protein NCU03235.1 ( XP 965335) which was denominated CYS-13 [57]. Since deletion of CYS-13 and CYS-14 leads to the inability to use sulphate for growth in other organisms [53], the remaining sulphate permeases are likely to have specialized functions and are not primarily involved in sulphate uptake under the conditions studied so far. Analysis of transcription of H. jecorina cys13 did not indicate expression of this sulphate permease under any conditions tested, including growth on glucose, glycerol or lactose (data not shown). Thus we conclude that cys13 does not compensate for the lack of $c y s 14$ and that uptake of sulphate in this fungus is altered as compared to Neurospora or Aspergillus.

\section{Expression of lim I and cellulase genes is dependent on the availability of the sulphur source}

The data described above suggests that availability as well as quality of the sulphur source are important for regulation of cellulase gene transcription and that the newly identified regulator protein LIMPET is involved in this process. If this would prove correct, then cellulase gene 


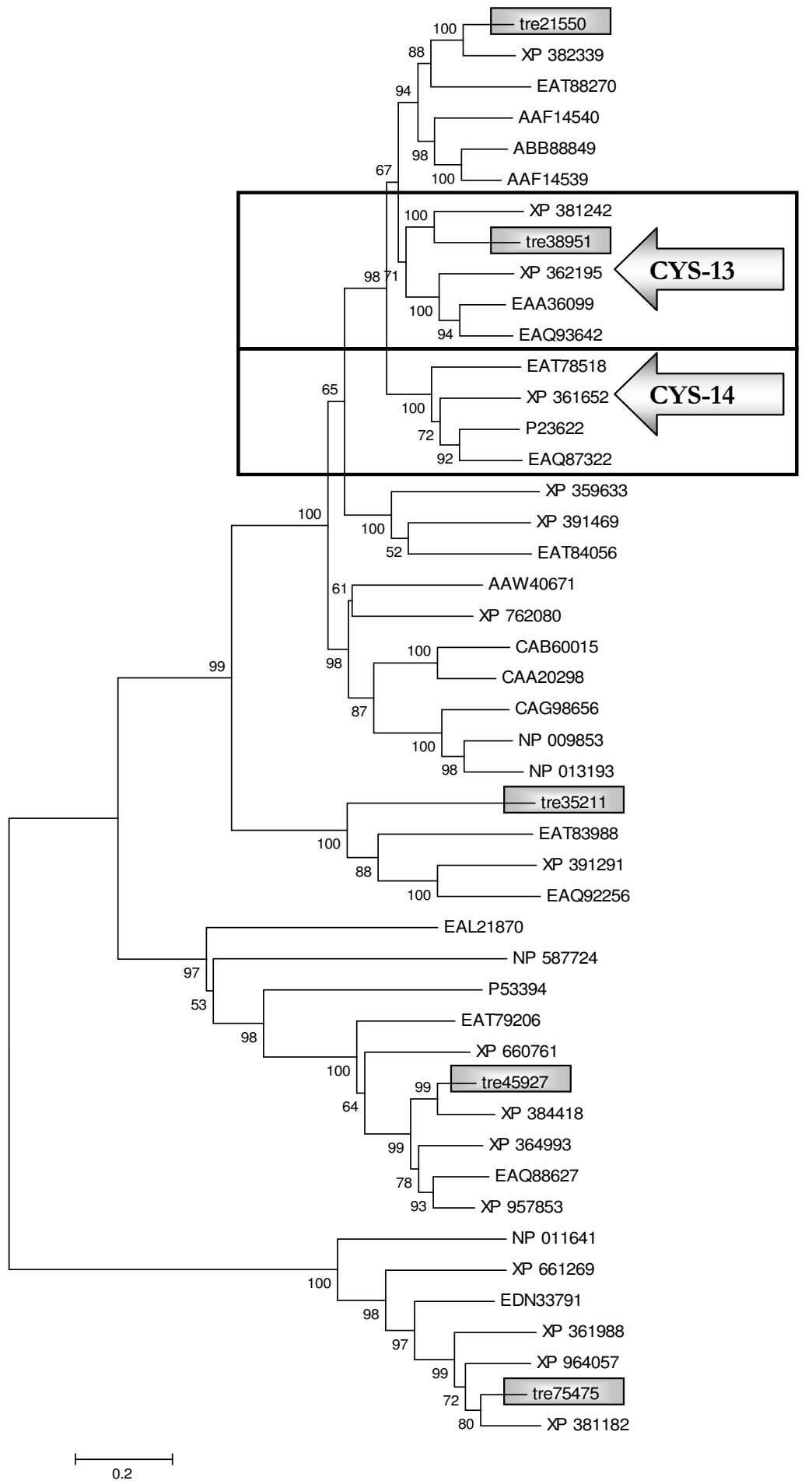

Figure 6

Phylogenetic analysis of sulphate permeases of $\boldsymbol{H}$. jecorina. Sulphate permeases present in the genome of $H$. jecorina and their nearest neighbours were analyzed with the software MEGA 4 using the Minimum evolution method. Description and GenBank accession numbers of the proteins used are listed in Table I. H. jecorina sulphate permeases are provided with the proteinID as given in the T. reesei genome database v2.0. Numbers at branches indicate their boostrap support. Clusters comprising homologues of $N$. crassa CYS- 13 and CYS-14, respectively, are boxed. 
Table I: Sequences used for phylogenetic analysis of sulphate permeases

\begin{tabular}{|c|c|}
\hline Accession No. & Description \\
\hline AAA33615 & Neurospora crassa sulfate permease II cys- I4 \\
\hline$\underline{A A B 67550}$ & Saccharomyces cerevisiae Sul2p: high affinity sulfate permease \\
\hline$\overline{A A F I 4539}$ & Penicillium chrysogenum sulphate permease SutB \\
\hline AAFI4540 & Penicillium chrysogenum sulphate permease SutA \\
\hline$\overline{\mathrm{AAw} 40671}$ & Cryptococcus neoformans sulfate transporter, putative \\
\hline ABB88849 & Aspergillus nidulans sulphate permease SULI \\
\hline CAA20298 & Schizosaccharomyces pombe sulphate permease SPBC3H7.02 \\
\hline$\overline{\text { CAA84506 }}$ & Saccharomyces cerevisiae sulfate permease. \\
\hline$\overline{\mathrm{CAB} 60015}$ & Schizosaccharomyces pombe sulphate permease SPAC869.05c \\
\hline$\overline{\text { CAG98656 }}$ & Kluyveromyces lactis unnamed protein product \\
\hline EAA28274 & Neurospora crassa sulphate permease NCU04433.I \\
\hline EAA36099 & Neurospora crassa hypothetical protein NCU03235.I \\
\hline EAL21870 & Cryptococcus neoformans hypothetical protein CNBCOI20 \\
\hline$\overline{\text { EAL21871 }}$ & Cryptococcus neoformans hypothetical protein CNBCOI20 \\
\hline EAL234I5 & Cryptococcus neoformans hypothetical protein CNBA0650 \\
\hline EAQ71607 & Magnaporthe grisea hypothetical protein MGG_ch7gI014 \\
\hline EAQ87322 & Chaetomium globosum hypothetical protein CHGG_0394I \\
\hline EAQ88627 & Chaetomium globosum hypothetical protein CHGG_05246 \\
\hline EAQ92256 & Chaetomium globosum hypothetical protein CHGG_0049I \\
\hline$\overline{\text { EAQ93642 }}$ & Chaetomium globosum hypothetical protein CHGG_01877 \\
\hline EAT78518 & Phaeosphaeria nodorum hypothetical protein SNOG_I428I \\
\hline$\overline{\text { EAT79206 }}$ & Phaeosphaeria nodorum hypothetical protein SNOG_I3322 \\
\hline$\overline{\text { EAT83988 }}$ & Phaeosphaeria nodorum hypothetical protein SNOG_08820 \\
\hline$\overline{\text { EAT } 84056}$ & Phaeosphaeria nodorum hypothetical protein SNOG_08888 \\
\hline EAT88270 & Phaeophaeria nodorum hypothetical protein SNOG_045I0 \\
\hline EDN33791 & Botryotinia fuckeliana hypothetical protein BCIG_I2094 \\
\hline NP 009853 & Saccharomyces cerevisiae sulphate permease Sullp \\
\hline NP 011641 & Saccharomyces cerevisiae putative protein of unknown function \\
\hline NP 013193 & Saccharomyces cerevisiae sulphate permease Sul2p \\
\hline NP 587724 & Schizosaccharomyces pombe hypothetical protein SPCC320.05 \\
\hline P23622 & Neurospora crassa sulphate permease 2 CYS-14 \\
\hline$\overline{\mathrm{P} 53394}$ & Saccharomyces cerevisiae Putative sulfate transporter YPR003C \\
\hline tre21550 & H. jecorina sulphate permease \\
\hline tre352II & H. jecorina sulphate permease \\
\hline tre3895I & $H$. jecorina sulphate permease \\
\hline tre45927 & H. jecorina sulphate permease \\
\hline tre75475 & H. jecorina sulphate permease \\
\hline XP 359633 & Magnaporthe grisea hypothetical protein MG05I44.4 \\
\hline XP 361652 & Magnaporthe grisea hypothetical protein MG04I26.4 \\
\hline$X P 361988$ & Magnaporthe grisea hypothetical protein MGG_04433 \\
\hline$\overline{X P \quad 362195}$ & Magnaporthe grisea hypothetical protein MG04640.4 \\
\hline$\overline{X P \quad 364993}$ & Magnaporthe grisea hypothetical protein MG09838.4 \\
\hline XP 366031 & Magnaporthe grisea hypothetical protein MG I025I.4 \\
\hline XP 381182 & Gibberella zeae hypothetical protein FG01006.I \\
\hline XP 381242 & Gibberella zeae hypothetical protein FG0I066.I \\
\hline$\overline{X P \quad 382339}$ & Gibberella zeae hypothetical protein FG02163.I \\
\hline XP 384418 & Gibberella zeae hypothetical protein FG04242.I \\
\hline XP 391291 & Gibberella zeae hypothetical protein FG IIII5.I \\
\hline$\overline{X P 391469}$ & Gibberella zeae hypothetical protein FG I I 293.I \\
\hline XP 660761 & Aspergillus nidulans hypothetical protein AN3 I57.2 \\
\hline XP 661269 & Aspergillus nidulans hypothetical protein AN3665.2 \\
\hline XP 762080 & Ustilago maydis hypothetical protein UM05933.I \\
\hline XP 957853 & Neurospora crassa hypothetical protein NCU09642.I \\
\hline
\end{tabular}


transcription should be influenced by the sulphur source in the medium and a correlation to $\lim 1$ transcription should occur. Since we detected a general influence of the sulphur source on growth on cellulose, we analyzed transcription of the main cellulase $c b h 1$. Also the promotor of cbh1 comprises a motif similar to the binding sequence analyzed in this study at -783 relative to the ATG. As cellulases are coregulated in $H$. jecorina $[20,59,60]$, transcription of $c b h 1$ can be considered representative for cellulase transcription. Transcript abundance of both $\lim 1$ and $c b h 1$ was analyzed upon growth in sulphate free medium supplemented with 0.05 (limiting), 0.25 (low) or $5 \mathrm{mM}$ (high) of methionine in constant light or constant darkness. With methionine as the sole sulphur source, lim1 was transcribed in the presence of low or limiting $(0.05$ and $0.25 \mathrm{mM}$ ) concentrations and in darkness only. The transcription of $c b h 1$ was regulated contrarily to $\lim 1$ being maximal at $5 \mathrm{mM}$ methionine in darkness thus indicating a stimulation by methionine (Figure 7A). In light no $\lim 1$ transcript was detectable, and cellulase transcript

A

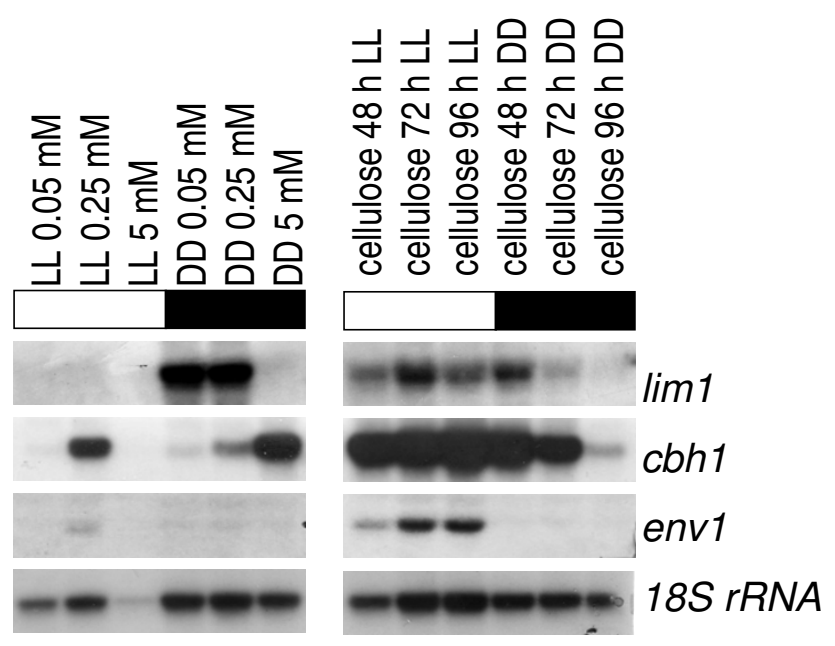

Figure 7

Northern analysis of transcription of $\lim I, c b h I$ and env I in constant light (LL; I 800 lux, $25 \mu \mathrm{mol}$ photons $\mathbf{m}^{-2} \mathbf{s}^{-1}$ ) or constant darkness (DD). (A) Strains were cultivated for 72 hours on Mandels Andreotti minimal medium lacking sulphate with $1 \%(\mathrm{w} / \mathrm{v})$ microcrystalline cellulose as sole carbon source and supplemented with $0.05,0.25$ or 5 $\mathrm{mM}$ methionine as specified with the samples. (B) Strains were cultivated for the time indicated with the samples on conventional Mandels Andreotti minimal medium with I\% (w/v) microcrystalline cellulose as sole carbon source, which comprises approximately $12 \mathrm{mM}$ sulphate and $0.25 \mathrm{mM}$ methionine due to the addition of peptone. $20 \mu \mathrm{g}$ of total RNA were loaded per lane, a hybridization with I 85 rRNA is given as a loading control. abundance in the presence of $0.25 \mathrm{mM}$ methionine was clearly elevated as compared to darkness, which is in concordance with earlier data [21]. However, no cellulase transcript was detected under sulphur limiting conditions in light. In the presence of $5 \mathrm{mM}$ methionine growth in light was severely reduced, which did not allow for a reliable result for this condition.

Due to the obvious indirect correlation of transcription of $\lim 1$ and $c b h 1$ in darkness, we were interested whether this correlation would also appear under commonly used conditions i. e. in conventional Mandels Andreotti medium, which contains $10 \mathrm{~g} / \mathrm{l}$ peptone (Merck, \#1.07213; corresponding to $0.25 \mathrm{mM}$ methionine) and approx. $12 \mathrm{mM}$ sulphate. Upon growth on conventional Mandels Andreotti medium, lim1 was detected not only in darkness, but also during growth in light. The complementary regulation of $\lim 1$ and $c b h 1$ as seen under controlled sulphur conditions and upon sophorose-induction was not obvious in conventional Mandels Andreotti medium (Figure $7 \mathrm{~B})$. Since no inorganic sulphate is available in the sulphate free Mandels Andreotti minimal medium, it seems likely that $\lim 1$ responds to the kind of sulphur source available or even specifically to the presence of methionine if sulphate is lacking both by an altered transcript level in general as well as by an altered response to light.

\section{lim I shows a transcriptional response to light and is regulated by ENVOY}

A light-dependent regulation of $\lim 1$ as indicated above would corroborate the obviously light dependent regulatory processes connected to sulphur metabolism. Therefore we were interested if transcription of $\lim 1$ would respond to illumination and if the light-regulatory protein ENVOY would be involved in the respective regulation. Upon growth on glucose lim1 showed enhanced transcription after a switch from constant darkness to constant light after 45 minutes on glucose. In the strain env1 $1^{\text {PAS- }}$ lacking the PAS-domain of the light regulatory protein ENVOY [21], transcription of $\lim 1$ is strongly increased in darkness and decreases upon illumination (Figure 8). Therefore $\lim 1$ is at least under some conditions subject to regulation by ENVOY. These data are indicative of regulation of $\lim 1$ by light, but also indicate that $\lim 1$ falls into the category of genes repressed by ENVOY in the dark [22]. The env1 transcript itself is responsive to limiting methionine levels, since it is more abundant in the presence of $0.25 \mathrm{mM}$ methionine as with only $0.05 \mathrm{mM}$ methionine (Figure 7A).

\section{Cellulase gene transcription is influenced contrarily in light and darkness by methionine}

Since the increased cellulase transcription upon addition of $5 \mathrm{mM}$ methionine in darkness (Figure 7A) could be exploited to enhance efficiency of industrial fermenta- 


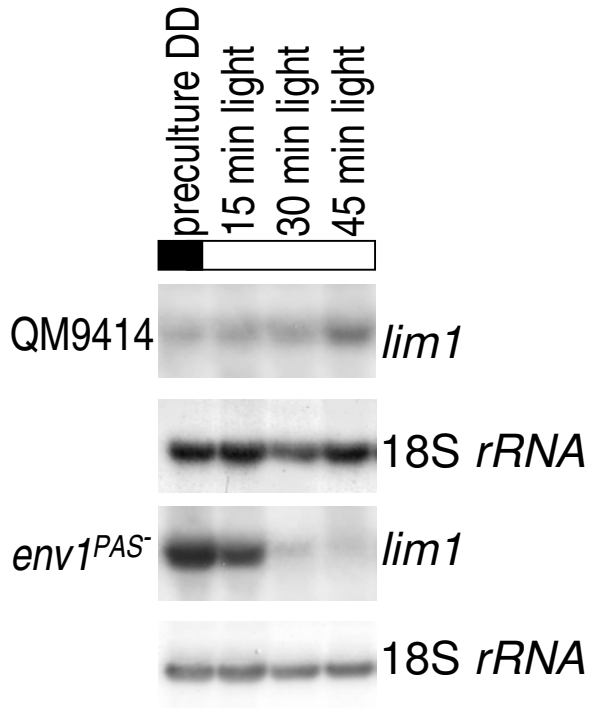

\section{Figure 8}

Northern analysis of transcription for analysis of light response of lim I. Transcription was analyzed in constant darkness (preculture, DD) and after illumination ( 800 lux, $25 \mu \mathrm{mol}$ photons $\mathrm{m}^{-2} \mathrm{~s}^{-1}$ ) for I5, 30 or 45 minutes in the wildtype strain QM94I4 and a strain lacking the PAS-domain of the light regulatory protein ENVOY (Schmoll et al., 2005). Strains were cultivated on conventional Mandels Andreotti minimal medium with I\% (w/v) glycerol as carbon source. 20 $\mu \mathrm{g}$ of total RNA were loaded per lane, a hybridization with I $8 \mathrm{~S}$ rRNA is given as a loading control.

tions, we wanted to test whether this enhancing effect of methionine would also occur under conditions commonly used with $H$. jecorina. The fungus was therefore grown on Mandels Andreotti minimal medium with 1\% $(\mathrm{w} / \mathrm{v})$ microcrystalline cellulose as carbon source and $0.1 \%$ peptone in light and darkness with or without $5 \mathrm{mM}$ methionine. In darkness we observed a threefold increase in transcript abundance of $c b h 1$ after 72 hours when methionine was added. In the presence of light, however, transcription of the major cellulase $c b h 1$ was completely shut down under the same conditions (Figure 9), although in this case the severe growth inhibition as seen without sulphate was not observed. Therefore $H$. jecorina most probably utilized the carbon content of peptone for growth, which however does not induce cellulase gene expression (M. Schmoll, unpublished). In accordance with its function as sulphur metabolite repressor, $\lim 1$ responded both in light and darkness to increased methionine levels with a shutdown of transcription. Thus lim1 specifically reacts to methionine levels in the medium, but - assuming cellulase genes to be a target of

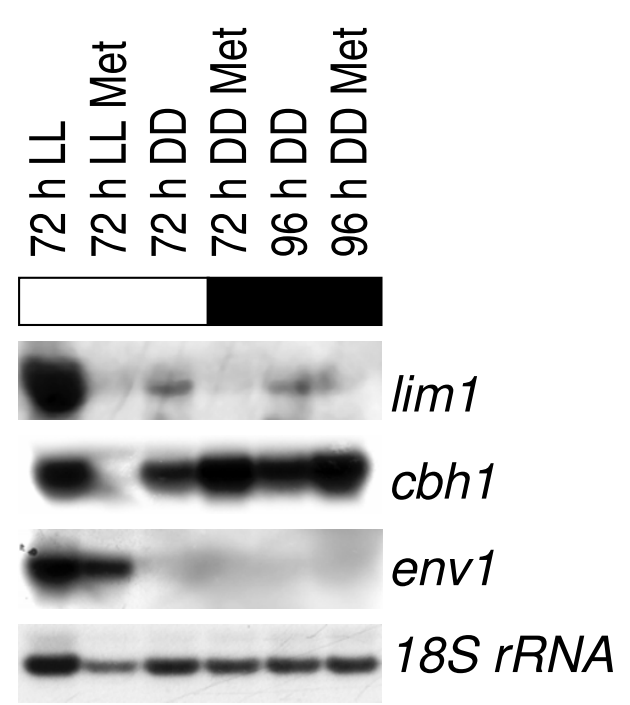

Figure 9

Northern analysis of transcription of $\lim I, c b h l$ and env I in constant light (LL; I 800 lux, $25 \mu \mathrm{mol}$ photons $\mathrm{m}^{-2} \mathrm{~s}^{-1}$ ) or constant darkness (DD). Strains were cultivated for 72 or 96 hours on conventional Mandels Andreotti minimal medium with $\mathrm{I} \%(\mathrm{w} / \mathrm{v})$ microcrystalline cellulose as sole carbon source. Met indicates addition of $5 \mathrm{mM}$ methionine to the culture. $20 \mu \mathrm{g}$ of total RNA were loaded per lane, a hybridization with I8S rRNA is given as a loading control. Transcript abundance was measured by densitometric scanning and normalization to the I8S rRNA loading control.

LIMPET - the output of its regulatory function depends on the light status.

\section{Discussion}

Sulphur uptake and metabolism are crucial processes for all organisms because of the manifold roles of the two sulphur containing amino acids cysteine and methionine not only in protein biosynthesis but also in redox potential homeostasis and methylation processes. Organisms have therefore developed sophisticated regulatory mechanisms to ensure controlled sulphur availability. As for fungi, the best analyzed machineries for this purpose are those of $N$. crassa, A. nidulans and particularly S. cerevisiae. In $H$. jecorina sulphur metabolism has not been studied so far.

The analysis of the influence of the sulphur source on regulation of cellulase gene expression was initiated by the unexpected finding, that LIMPET binds to a cis-regulatory motif of the $c b h 2$ promotor. LIMPET is the first WDrepeat/F-box protein to be identified and characterized in $H$. jecorina. Concluding from the functions of its orthologues in other fungi, LIMPET could be a regulatory protein that activates transcription by phosphorylation- 
dependent degradation of a factor inhibiting expression of $c b h 2$. Such a function would be in agreement with data from Zeilinger et al., [23], who showed that the complexes formed on CAE (the cbh2 activating element) are smaller under inducing conditions (sophorose), albeit the respective kinase and this probably repressing factor remain to be identified. Given the fact that E3 ubiquitin ligases themselves are frequently targets of degradation in an SCF-dependent manner [61,62], LIMPET could also itself represent this repressor. While deletion of the lim1-orthologues scon2 (Neurospora crassa) or sconb (Aspergillus nidulans) was successful, we were not able to obtain viable lim1-deletion mutants, what may be due to the obviously altered sulphur regulatory pathway. Interestingly, the $S$. cerevisiae orthologue of lim1, met30 is also an essential gene [8]. Nevertheless, we can therefore not be sure, whether LIMPET is indeed the transducer of the sulphur signal to the $c b h 2$-promotor and thus a direct regulator of cellulase gene expression, although a connection between sulphur- and carbon-signaling became clearly obvious.

A hypothesis how LIMPET could impact cellulase gene expression can be deduced from the studies on regulation of sulphur metabolism in $N$. crassa: The regulatory cycle of SCON-2 and CYS-3 has been analyzed in detail in $N$. crassa and involves both regulation of transcription and activation of the respective proteins. During sulphur limitation, SCON-2 is present in high amounts, most probably in an inactive state. If the nutritional situation changes and an abundant sulphur source is encountered, this pool of SCON-2 can be rapidly activated and prevent the function of CYS-3, and thus shut down the sulphur circuit. This finally results in the termination of sulphur uptake. On the other hand expression of the scon-2 gene, the promotor of which contains several CYS-3 binding sites, is dependent on functional CYS-3 $[6,63]$. Thus, SCON-2 inhibits $c y s 3$ transcription in a negative feedback loop [7]. CYS-3 activates the uptake of sulphate and several other mechanisms involved in sulphur metabolism [7]. Our data show that $\lim 1$ is not transcribed in light under conditions lacking an inorganic sulphur source. A function of LIMPET putatively analogous to SCON2 would thus lead to stimulated uptake of sulphate in light, which is not available under the condition tested, obviously resulting in considerably decreased growth. Also the decreasing effect of selenate upon growth on carboxymethylcellulose in light is in agreement with these data. Hence we conclude that sulphate is important for normal growth in light on cellulose and that methionine, being commonly considered an organic sulphur source, cannot compensate for this requirement. However, we want to note that despite the presence of a CYS-3 homologue, no binding sites similar to those identified in $N$. crassa were detected in the promotor of lim1. Hence a negative feedback loop may not be operative in $H$. jecorina.
Although the finding of LIMPET as a close homologue of N. crassa SCON-2 or A. nidulans SCONB, respectively, suggests similarities in the sulphur regulatory systems of Hypocrea, Neurospora and Aspergillus, the mechanism of sulphate uptake in Hypocrea jecorina QM9414 appears to be altered: First, phylogenetic analysis of its predicted sulphate permeases indicates, that the predominantly mycelial sulphate permease (the CYS-14 orthologue) is missing. Transcription of the remaining, predominantly conidial sulphate permease (the CYS-13 orthologue) could not be detected under any conditions tested (M. Schmoll, data not shown). In this respect it is particularly interesting, that lack of the two sulphate permeases CYS13 and CYS-14 leads to the inability to use sulphate as sulphur source and to selenate resistence [53] in N. crassa, although 4 sulphate permease genes have been detected in this fungus [57]. For both $N$. crassa and A. nidulans $[5,51]$ sensitivity versus toxic sulphur analogues in presence of low concentrations $(0.25 \mathrm{mM})$ of methionine was described, which is not found for H. jecorina. In S. cerevisiae, regulation of the synthesis of both sulphate permeases is under the control of exogenous methionine or S-adenosylmethionine. Their synthesis is coordinated with the synthesis of the other methionine biosynthetic enzymes [64], what would imply continued uptake of selenate and thus lethality under low-methionine conditions. Judging from this data, the $H$. jecorina sulphur assimilation system appears to exhibit high affinity versus methionine, enabling the fungus to survive even in the presence of very low concentrations of it. Since this fungus can also utilize sulphate as sole sulphur source, it is likely that $H$. jecorina is - obviously unlike A. nidulans or $N$. crassa - able to differentiate between these sulphur sources (which is also reflected by the transcription pattern of $\lim 1$ on media with or without sulphate) and terminate one uptake mechanism in favour of the other if required. In case of the presence of selenate such a flexible mechanism could prevent the fatal effect of this sulphate analogon, although therefore a specific detection of the toxin would be required. Alternatively an as yet unidentifed detoxification mechanism, which would explain this effect could be at work. In this respect it is interesting, that for several yeast species growing on decaying fruits comparable mechanisms have been detected and suggested to have evolved due to the considerable amounts of selenate present in certain plants. In order to avoid the harmful consequences of sulphate and thus selenate uptake they can preferentially utilize organic sulphur, in many cases obtained by attacking other yeasts $[65,66]$. Data on the role of the S. cerevisiae homologue of LIMPET, Met30p clearly show a role of the sulphur regulatory machinery in heavy metal response through regulation of the transcription factor Met4p [11]. The main target of this circuit in this case is glutathione synthesis, which is needed to complex and subsequently detoxify the heavy metal. A mech- 


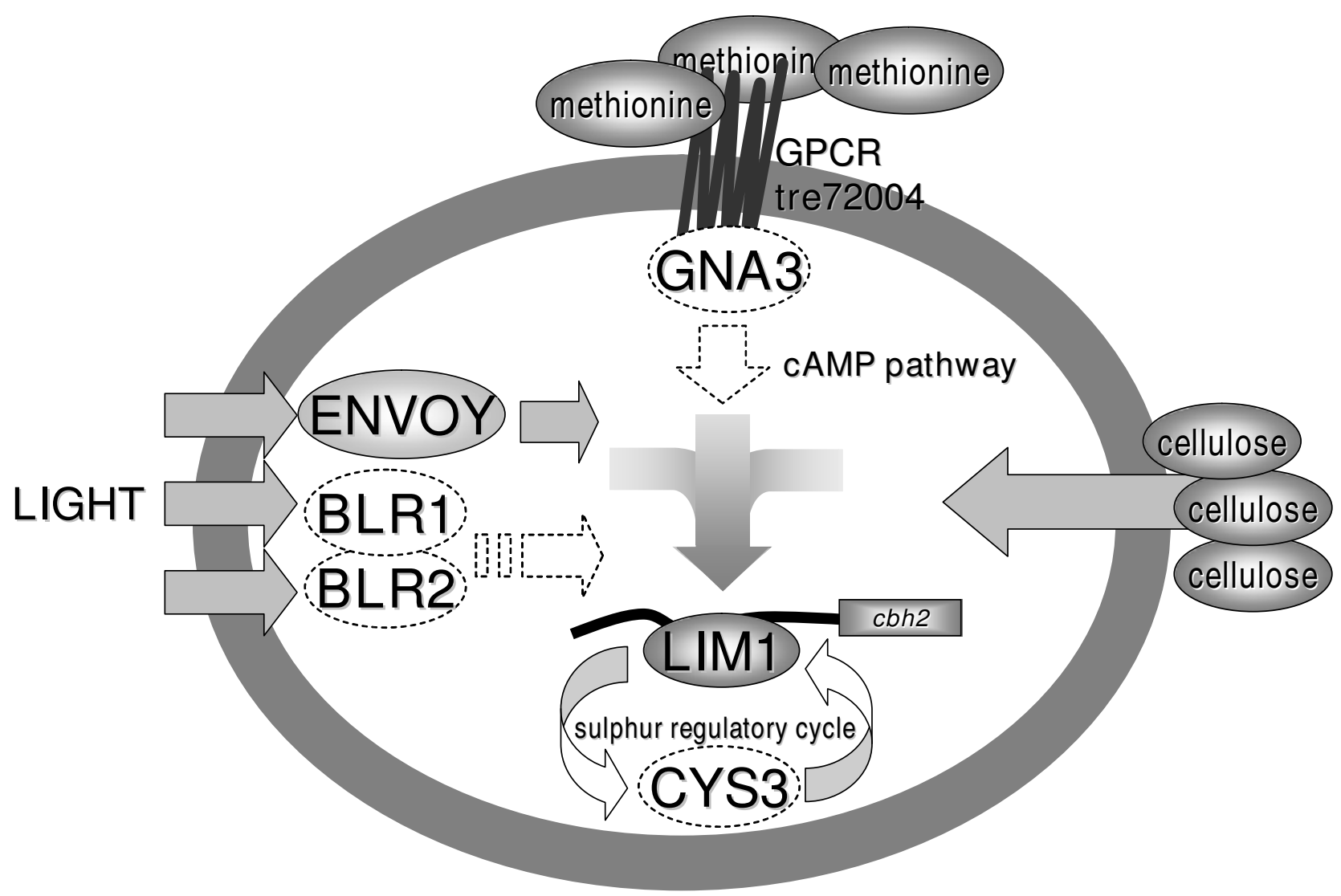

Figure 10

Model of regulatory inputs on LIMPET and thus cellulase gene expression. Environmental cues investigated in this study are represented in full, additional hypothetical components of the regulatory network as inferred by reports from other fungi are given as empty circles/arrows with dotted lines.

anism as described above would be in concordance with the symbiotic interaction of Trichoderma spp. with plants [67], their natural substrate being decaying plant material and their efficient biocontrol activity [68]. The fact that both the presence of selenate/sulphate or methionine, respectively, has different consequences in light and darkness further indicates that these environmental cues must have a more significant relevance than just signalling the availability of sulphur. In accordance with this hypothesis we found that $H$. jecorina adjusts cellulase gene transcription in dependence of the sulphur source available and the light status. Considering the mechanisms discussed above the connecting environmental cues might be the presence of plant material (cellulose) and possibly the encounter of a competitor, which is more likely on the surface of the substrate (light).

Consequently, an involvement of LIMPET in modulation of cellulase gene expression in response to a varying sup- ply of sulphur seems to be beneficial for H. jecorina. Interestingly, the respective signal leads to opposite effects in light and darkness in the presence of sulphate. Therefore we hypothesize that the significance of the presence of methionine reaches beyond merely an indication of the sulphur source. Since the addition of methionine did not stimulate growth on cellulose in light in the absence of sulphate, we assume that its effect is also not simply related to the provision of a potentially growth-limiting amino acid. The response to methionine may be - at least in part - connected to the intracellular cAMP-levels which has been shown to stimulate cellulase formation in $H$. jecorina [69] and Cryphonectria parasitica [70]. While the enhanced transcription of $c b h 1$ upon addition of methionine in darkness is well in concordance with this hypothesis, the abolished $c b h 1$ transcription under the same conditions in light rather indicates a more sophisticated regulation. A recent study by Xue and coworkers [71] provides intriguing hints which might shed a new light on the 
interacting signal transduction pathways studied in this work. They show that the G-protein coupled receptor GPR4 of Cryptococcus neoformans, which has an orthologue in H. jecorina (tre72004), interacts with the G-protein $\alpha$ subunit GPA1, the orthologue of H. jecorina GNA3 and that methionine induces cAMP accumulation in this fungus. This study on the one hand shows that this G-protein coupled receptor does not respond to glucose as expected from its structural similarity to the $S$. cerevisiae glucose sensor GPR1, but instead seems to sense methionine this amino acid being the only clearly confirmed ligand of GPR4. On the other hand, its interacting G-protein $\alpha$ subunit GPA1 is involved in glucose sensing. Also, methionine was found to induce cAMP accumulation in $C$. neoformans.

\section{Conclusion}

Out data revealed that cellulase gene expression is influenced by both quality and quantity of the sulphur source available and that the regulation of sulphur metabolism and -uptake in H. jecorina is different compared to other fungi. Thereby, the methionine signal seems not only to be representative for the presence of a sulphur source, but also has a light dependent significance for cellulase transcription. We hypothesize that $H$. jecorina GNA3, which we found to be involved in regulation of cellulase gene expression (manuscript submitted), could establish the connection between the putative methionine receptor and the target (Figure 10). Light dependent regulation of $\lim 1$ transcription in the presence of high amounts of inorganic sulphate and low methionine concentrations suggests that $\lim 1$ also responds to the kind of sulphur source available and might affect its targets accordingly. For SCON2 [51] and SCONB [5], although grown on glucose and without controlled light conditions, essentially similar transcriptional behaviour as observed with $\lim 1$ in darkness in the absence of sulphate, was reported. Therefore the function of $\lim 1$ is unlikely to be shifted from regulation of sulphate to regulation of carbon metabolism but lies rather in the connection of these pathways. Such a system would resemble a nutrient coincidence detection system as suggested by Xue and coworkers [71], which additionally integrates the light status into the regulation of transmission of the signal to its target.

\section{Authors' contributions}

GG carried out the transcription analyses on cellulose and participated in drafting the manuscript. MD worked on deletion of $\lim 1$ and performed studies on selenate sensitivity. MS carried out the One Hybrid System, selection of positive clones, phylogenetic analyses, transcription analysis of response of $\lim 1$ to different sulphur conditions, cellulase inducing conditions and light response. MS conceived of the study and wrote the manuscript.

\section{Acknowledgements}

We want to thank Christian P. Kubicek for critically reading the manuscript and S. Zeilinger and R. Mach for assistance in designing the One Hybrid experiment. This work has been supported by grants from the Austrian Science Foundation (FWF-PI7325) to Christian P. Kubicek. MS is recipient of an APART fellowship of the Austrian Academy of Sciences at the Institute of Chemical Engineering, TU Vienna. The T. reesei genome sequencing project was funded by the Department of Energy, USA.

\section{References}

I. Marzluf GA: Molecular genetics of sulfur assimilation in filamentous fungi and yeast. Annu Rev Microbiol I 997, 5 I:73-96.

2. Paietta JV, Akins RA, Lambowitz AM, Marzluf GA: Molecular cloning and characterization of the cys-3 regulatory gene of $\mathrm{Neu}$ rospora crassa. Mol Cell Biol I987, 7(7):2506-25II.

3. Thomas D, Jacquemin I, Surdin-Kerjan Y: MET4, a leucine zipper protein, and centromere-binding factor $I$ are both required for transcriptional activation of sulfur metabolism in Saccharomyces cerevisiae. Mol Cell Biol 1992, I2(4): I719-1727.

4. Natorff R, Balinska $M$, Paszewski A: At least four regulatory genes control sulphur metabolite repression in Aspergillus nidulans. Mol Gen Genet 1993, 238(1-2): I85-192.

5. Natorff R, Piotrowska M, Paszewski A: The Aspergillus nidulans sulphur regulatory gene scon $B$ encodes a protein with WD40 repeats and an F-box. Mol Gen Genet 1998, 257(3):255-263.

6. Kumar A, Paietta JV: The sulfur controller-2 negative regulatory gene of Neurospora crassa encodes a protein with beta-transducin repeats. Proc Natl Acad Sci USA 1995, 92(8):3343-3347.

7. Kumar A, Paietta JV: An additional role for the F-box motif: gene regulation within the Neurospora crassa sulfur control network. Proc Natl Acad Sci USA 1998, 95(5):24I 7-2422.

8. Thomas D, Kuras L, Barbey R, Cherest H, Blaiseau PL, Surdin-Kerjan $Y$ : Met30p, a yeast transcriptional inhibitor that responds to S-adenosylmethionine, is an essential protein with WD40 repeats. Mol Cell Biol 1995, I 5( I 2):6526-6534.

9. Yen JL, Su NY, Kaiser P: The yeast ubiquitin ligase SCFMet30 regulates heavy metal response. Mol Biol Cell 2005, I 6(4): 1872-1882.

10. Maruyama-Nakashita A, Nakamura Y, Yamaya T, Takahashi H: Regulation of high-affinity sulphate transporters in plants: towards systematic analysis of sulphur signalling and regulation. J Exp Bot 2004, 55(404): I843-1849.

II. Baudouin-Cornu P, Labarre J: Regulation of the cadmium stress response through SCF-like ubiquitin ligases: comparison between Saccharomyces cerevisiae, Schizosaccharomyces pombe and mammalian cells. Biochimie 2006, 88(I I): I673-I685.

12. Barbey R, Baudouin-Cornu P, Lee TA, Rouillon A, Zarzov P, Tyers M, Thomas D: Inducible dissociation of SCF(Met30) ubiquitin ligase mediates a rapid transcriptional response to cadmium. Embo J 2005, 24(3):52I-532.

13. Fauchon M, Lagniel G, Aude JC, Lombardia L, Soularue P, Petat C, Marguerie G, Sentenac A, Werner M, Labarre J: Sulfur sparing in the yeast proteome in response to sulfur demand. Mol Cell 2002, 9(4):713-723.

14. Haugen AC, Kelley R, Collins JB, Tucker CJ, Deng C, Afshari CA, Brown JM, Ideker T, van Houten B: Integrating phenotypic and expression profiles to map arsenic-response networks. Genome Biol 2004, 5( I 2):R95.

15. Pinson B, Sagot I, Daignan-Fornier B: Identification of genes affecting selenite toxicity and resistance in Saccharomyces cerevisiae. Mol Microbiol 2000, 36(3):679-687.

16. Buchert J, Oksanen T, Pere J, Siika-Aho M, Suurnäkki A, Viikari L: Applications of Trichoderma reesei enzymes in the pulp and paper industry. In Trichoderma \& Gliocladium Volume 2. Edited by: Harman GE, CP K. London: Taylor \& Francis; 1998:343-363.

17. Galante Y, De Conti A, Monteverdi R: Application of Trichoderma enzymes in the textile industry. In Trichoderma \& Gliocladium Edited by: Harman GE, KC. London: Taylor \& Francis; 1998:3 I I-325.

18. Galante Y, De Conti A, Monteverdi R: Application of Trichoderma enzymes in the food and feed industries. In Trichoderma and Gliocladium Edited by: Harman GE, Kubicek CP. London: Taylor \& Francis; 1998:327-342. 
19. Martinez D, Berka RM, Henrissat B, Saloheimo M, Arvas M, Baker SE, Chapman J, Chertkov O, Coutinho PM, Cullen D, et al.: Genome sequencing and analysis of the biomass-degrading fungus Trichoderma reesei (syn. Hypocrea jecorina. Nat Biotechnol 2008, 26(5):553-560.

20. Schmoll M, Kubicek CP: Regulation of Trichoderma cellulase formation: lessons in molecular biology from an industrial fungus. A review. Acta Microbiol Immunol Hung 2003, 50(2-3): I 25- I 45.

21. Schmoll M, Franchi L, Kubicek CP: Envoy, a PAS/LOV domain protein of Hypocrea jecorina (Anamorph Trichoderma reesei), modulates cellulase gene transcription in response to light. Eukaryot Cell 2005, 4( I 2): 1998-2007.

22. Schuster A, Kubicek CP, Friedl MA, Druzhinina IS, Schmoll M Impact of light on Hypocrea jecorina and the multiple cellular roles of ENVOY in this process. BMC Genomics 2007, 8(I):449.

23. Zeilinger S, Mach RL, Kubicek CP: Two adjacent protein binding motifs in the cbh2 (cellobiohydrolase Il-encoding) promoter of the fungus Hypocrea jecorina (Trichoderma reesei) cooperate in the induction by cellulose. J Biol Chem 1998, 273(5 I):34463-3447I.

24. Zeilinger S, Ebner A, Marosits T, Mach R, Kubicek CP: The Hypocrea jecorina HAP $2 / 3 / 5$ protein complex binds to the inverted CCAAT-box (ATTGG) within the cbh2 (cellobiohydrolase IIgene) activating element. Mol Genet Genomics 200I, 266(I):56-63.

25. Aro N, Pakula T, Penttila M: Transcriptional regulation of plant cell wall degradation by filamentous fungi. FEMS Microbiol Rev 2005, 29(4):719-739.

26. Aro N, Saloheimo A, Ilmen M, Penttila M: ACEII, a novel transcriptional activator involved in regulation of cellulase and xylanase genes of Trichoderma reesei. I Biol Chem 2001, 276(26):24309-24314.

27. Rauscher R, Wurleitner E, Wacenovsky C, Aro N, Stricker AR, Zeilinger S, Kubicek CP, Penttila M, Mach RL: Transcriptional regulation of xyn I, encoding xylanase I, in Hypocrea jecorina. Eukaryot Cell 2006, 5(3):447-456.

28. Stricker AR, Grosstessner-Hain K, Wurleitner E, Mach RL: Xyr I (Xylanase Regulator I) Regulates both the Hydrolytic Enzyme System and D-Xylose Metabolism in Hypocrea jecorina. Eukaryot Cell 2006, 5(12):2128-2I37.

29. Mandels $M$, Andreotti R: Problems and challenges in the cellulose to cellulase fermentation. Proc Biochem 1978, I3:6-13.

30. Sternberg D, Mandels GR: Induction of cellulolytic enzymes in Trichoderma reesei by sophorose. J Bacteriol 1979, 139(3):761-769.

31. Schmoll M, Zeilinger S, Mach RL, Kubicek CP: Cloning of genes expressed early during cellulase induction in Hypocrea jecorina by a rapid subtraction hybridization approach. Fungal Genet Biol 2004, 4 I (9):877-887.

32. Liu J, Wilson TE, Milbrandt J, Johnston M: Identifying DNA-binding sites and analyzing DNA-binding domains using a yeast selection system. Methods: A Companion to Methods in Enzymology 1993, 5:125-137.

33. Wilson TE, Fahrner TJ, Johnston M, Milbrandt J: Identification of the DNA binding site for NGFI-B by genetic selection in yeast. Science 1991, 252:1296-1300.

34. Yanisch-Perron C, Vieira J, Messing J: Improved MI3 phage cloning vectors and host strains: nucleotide sequences of the MI3mp I 8 and pUCI 9 vectors. Gene 1985, 33(I): I03-II9.

35. Sambrook J, Fritsch EF, Maniatis T: Molecular cloning: a Laboratory Manual. 2nd edition. NY: Cold Spring Harbour Laboratory Press; 1989.

36. Chomczynski P, Sacchi N: Single-step method of RNA isolation by acid guanidinium thiocyanate-phenol-chloroform extraction. Anal Biochem 1987, I 62(I): 156-159.

37. Gietz RD, Woods RA: Transformation of yeast by the lithium acetate/single stranded carrier DNA/PEG method. Methods in Enzymology 2002, 350:87-96.

38. Ausubel FM, Brent R, Kingston RE, Moore DD, Seidman JG, Smith JA Struhl K: Current Protocols in Molecular Biology. New York: Greene Publishing Associates and Wiley-Interscience; 1993.

39. Trichoderma reesei genome database ver2.0 [http://genome.jgipsf.org/Trire2/Trire2.home.html]

40. Smith DB, Johnson KS: Single-step purification of polypeptides expressed in Escherichia coli as fusions with glutathione Stransferase. Gene 1988, 67(I):31-40.
41. Stangl H, Gruber F, Kubicek CP: Characterization of the Trichoderma reesei cbh2 promoter. Curr Genet 1993, 23(2): I I 5- I 22.

42. Thompson JD, Gibson TJ, Plewniak F, Jeanmougin F, Higgins DG: The CLUSTAL_X windows interface: flexible strategies for multiple sequence alignment aided by quality analysis tools. Nucleic Acids Res 1997, 25(24):4876-4882.

43. Felsenstein J: Confidence limits on phylogenies: An approach sing the bootstrap. Evolution 1985, 39:783-791.

44. Chong JA, Mandel G: Isolation of DNA-bindng proteins using One Hybrid Genetic Screens. In The Yeast Two Hybrid System Edited by: Bartel PLFS. New York: Oxford University Press; 1997:289-297.

45. Kadonga JT, Tijan KR: Affinity purification of sequence-specific DNA binding proteins. Proc Natl Acad Sci 1986, 83:5889-5893.

46. Singh H, Lebowitz JH, Baldwin JAS, Sharp PA: Molecular cloning of an enhancer binding-protein: isolation by screening of an expression library with a recognition site DNA. Cell 1988, 52:4I5-423.

47. Schouten J, de Kam RJ, Fetter K, Hoge JH: Overexpression of Arabidopsis thaliana SKPI homologues in yeast inactivates the Mig I repressor by destabilising the F-box protein Grr I. Mol Gen Genet 2000, 263(2):309-319.

48. Psort II protein analysis server [http://psort.ims.u-tokyo.ac.jp/]

49. Reinhardt A, Hubbard T: Using neural networks for prediction of the subcellular location of proteins. Nucleic Acids Res 1998 , 26(9):2230-2236

50. Bai C, Sen P, Hofmann K, Ma L, Goebl M, Harper JW, Elledge SJ: SKPI connects cell cycle regulators to the ubiquitin proteolysis machinery through a novel motif, the F-box. Cell 1996, 86(2):263-274.

5I. Paietta JV: Molecular cloning and analysis of the scon-2 negative regulatory gene of Neurospora crassa. Mol Cell Biol 1990 I 0( I 0):5207-5214

52. NCBI Blast server [http://www.ncbi.nlm.nih.gov/BLAST/]

53. Marzluf GA: Genetic and metabolic controls for sulfate metabolism in Neurospora crassa: isolation and study of chromate-resistant and sulfate transport-negative mutants. J Bacteriol 1970, I02(3):716-72I.

54. Raspor $P$, Fujs S, Banszky L, Maraz A, Batic M: The involvement of ATP sulfurylase in $\mathrm{Se}(\mathrm{VI})$ and $\mathrm{Cr}(\mathrm{VI})$ reduction processes in the fission yeast Schizosaccharomyces pombe. Appl Microbiol Biotechnol 2003, 63(I):89-95.

55. Banszky L, Simonics T, Maraz A: Sulphate metabolism of selenate-resistant Schizosaccharomyces pombe mutants. J Gen Appl Microbiol 2003, 49(5):27I-278.

56. Letavayova L, Vlasakova D, Spallholz JE, Brozmanova J, Chovanec M: Toxicity and mutagenicity of selenium compounds in Saccharomyces cerevisiae. Mutat Res 2008, 638(I-2): I-I0.

57. Borkovich KA, Alex LA, Yarden O, Freitag M, Turner GE, Read ND, Seiler S, Bell-Pedersen D, Paietta J, Plesofsky N, et al.: Lessons from the genome sequence of Neurospora crassa: tracing the path from genomic blueprint to multicellular organism. Microbiol Mol Biol Rev 2004, 68(I): I- 108.

58. Ketter JS, Marzluf GA: Molecular cloning and analysis of the regulation of cys-I4+, a structural gene of the sulfur regulatory circuit of Neurospora crassa. Mol Cell Biol 1988, 8(4): I504-1508.

59. Foreman PK, Brown D, Dankmeyer L, Dean R, Diener S, Dunn-Coleman NS, Goedegebuur F, Houfek TD, England GJ, Kelley AS, et al: Transcriptional regulation of biomass-degrading enzymes in the filamentous fungus Trichoderma reesei. J Biol Chem 2003, 278(34):3 I 988-31997.

60. Ilmen M, Saloheimo A, Onnela ML, Penttila ME: Regulation of cellulase gene expression in the filamentous fungus Trichoderma reesei. Appl Environ Microbiol I997, 63(4): I298-I306.

61. Craig KL, Tyers M: The F-box: a new motif for ubiquitin dependent proteolysis in cell cycle regulation and signal transduction. Prog Biophys Mol Biol 1999, 72(3):299-328.

62. Kaplan KB, Hyman AA, Sorger PK: Regulating the yeast kinetochore by ubiquitin-dependent degradation and Skp I p-mediated phosphorylation. Cell I997, 91(4):49|-500.

63. Marzluf GA: Metabolic regulation in fungi. In Applied mycology and biotechnology Volume I. Khachatourians GG, Arora DK; 200 I:55-72.

64. Breton A, Surdin-Kerjan Y: Sulfate uptake in Saccharomyces cerevisiae: biochemical and genetic study. J Bacteriol 1977, I 32( I):224-232. 
65. Lachance MA, Pang WM: Predacious yeasts. Yeast 1997, I3(3):225-232.

66. Scheibel T, Bell S, Walke S: S. cerevisiae and sulfur: a unique way to deal with the environment. Faseb J 1997, I I (I I):917-92 I.

67. Harman GE, Howell CR, Viterbo A, Chet I, Lorito M: Trichoderma species - opportunistic, avirulent plant symbionts. Nat Rev Microbiol 2004, 2(I):43-56.

68. Benitez T, Rincon AM, Limon MC, Codon AC: Biocontrol mechanisms of Trichoderma strains. Int Microbiol 2004, 7(4):249-260.

69. Sestak S, Farkas V: Metabolic regulation of endoglucanase synthesis in Trichoderma reesei: participation of cyclic AMP and glucose-6-phosphate. Can J Microbiol I993, 39(3):342-347.

70. Segers GC, Nuss DL: Constitutively activated Galpha negatively regulates virulence, reproduction and hydrophobin gene expression in the chestnut blight fungus Cryphonectria parasitica. Fungal Genet Biol 2003, 38(2): 198-208.

7I. Xue C, Bahn YS, Cox GM, Heitman J: G protein-coupled receptor Gpr4 senses amino acids and activates the CAMP-PKA pathway in Cryptococcus neoformans. Mol Biol Cell 2006, I 7(2):667-679.

72. Neer EJ, Schmidt CJ, Nambudripad R, Smith TF: The ancient regulatory-protein family of WD-repeat proteins. Nature 1994, 37 I(6495):297-300.

Publish with Bio Med Central and every scientist can read your work free of charge

"BioMed Central will be the most significant development for disseminating the results of biomedical research in our lifetime. "

Sir Paul Nurse, Cancer Research UK

Your research papers will be:

- available free of charge to the entire biomedical community

- peer reviewed and published immediately upon acceptance

- cited in PubMed and archived on PubMed Central

- yours - you keep the copyright

Submit your manuscript here:

http://www.biomedcentral.com/info/publishing_adv.asp
BioMedcentral 